\title{
Rhizosphere priming of barley with and without root hairs
}

Johanna Pausch ${ }^{1 *}$, Sebastian Loeppmann ${ }^{1}$, Anna Kühnel ${ }^{2}$, Kelsey Forbush ${ }^{3}$, Yakov Kuzyakov ${ }^{1,4}$, Weixin Cheng ${ }^{3}$

${ }^{1}$ Department of Soil Science of Temperate Ecosystems, Georg August University Göttingen, Germany

${ }^{2}$ Department of Soil Science, Technical University of Munich, Freising, Germany

${ }^{3}$ Department of Environmental Studies, University of California, Santa Cruz, CA, USA

${ }^{4}$ Department of Agricultural Soil Science, Georg August University Göttingen, Germany

${ }^{*}$ Corresponding author: Department of Soil Science of Temperate Ecosystems, University of Göttingen, Büsgen-Institute, Büsgenweg 2, 37077 Göttingen, Germany. Phone: +495513933507 Fax: +495513933310

E-mail: jpausch@gwdg.de 


\section{Abstract}

The influence of plant roots and the associated rhizosphere activities on decomposition of soil organic matter (SOM), the rhizosphere priming effect, has emerged as a crucial mechanism regulating global carbon $(\mathrm{C})$ and nitrogen $(\mathrm{N})$ cycles. However, the role of root morphology in controlling the rhizosphere priming effect remains largely unknown. To investigate the link between root hairs, a critical part of the entire root morphology, and the rhizosphere priming effect, we grew a barley wild type and a barley mutant without root hairs in a greenhouse and continuously labeled them with ${ }^{13} \mathrm{C}$-depleted $\mathrm{CO}_{2}$. Soil $\mathrm{CO}_{2}$ efflux was measured during tillering and head-emergence stages of plant growth. Based on its $\delta^{13} \mathrm{C}$ signature, total $\mathrm{CO}_{2}$ was partitioned for root-derived and $\mathrm{SOM}$-derived $\mathrm{CO}_{2}$, and the SOM decomposition primed in the rhizosphere was calculated. Soil microbial biomass $\mathrm{C}$ and $\mathrm{N}$, and the activities of six extracellular enzymes ( $\beta$-cellobiohydrolase, $\beta$-glucosidase, acid phosphatase, $\beta$-xylosidase, leucin-aminopeptidase, and N-acetyl$\beta$-glucosaminidase) were measured to test the effects of root hairs.

During the early stage of development (tillering), when plants were sufficiently supplied with nutrients, the barley mutant without root hairs produced more shoot biomass. In contrast, high $\mathrm{C}$ costs for root-hair formation likely reduced the growth of the barley wild type. At this stage, the wild type with regular root hairs produced a positive rhizosphere priming effect ( $69 \%$ increase), but the mutant without root hairs produced a negative priming effect on SOM decomposition ( $28 \%$ decline). At the head-emergence stage, when nutrients were scarce, plant biomass production of the mutant was reduced, probably due to inefficient nutrient uptake in the absence of root hairs. At this stage, both barley types produced positive rhizosphere priming effects (72\% and $209 \%$ increase for the wild type and the mutant, respectively) and the microbial biomass was higher for both planted soils compared to the tillering stage. 
Extracellular enzymes responsible for the decomposition of stable SOM had higher activities in cases of positive priming effects. Overall, root hairs appear to play an important role in regulating rhizosphere priming.

Key words: Soil $\mathrm{CO}_{2}$ efflux; Root morphology; Root hairless Barley mutant; Isotope labeling; Enzyme activities

\section{Introduction}

Soil $\mathrm{CO}_{2}$ is one of the largest fluxes in the global $\mathrm{C}$ cycle, approximately ten-fold greater than $\mathrm{CO}_{2}$ emissions from fossil fuel combustion (Schlesinger and Andrews, 2000; Amundson, 2001). The majority of this flux results from the decomposition of soil organic matter (SOM) and litter by microbes (Kuzyakov, 2006). In recent years, there is an emerging view that, in addition to temperature and moisture, carbon substrate availability is a key factor controlling SOM turnover (Fontaine et al., 2007; Paterson and Sim, 2013). These changes in the rate of SOM turnover following the input of easily decomposable substrates for microorganisms are termed 'priming effects'.

While decaying leaf and root litter provides some labile substrate for soil microbes, the majority of the labile substrate in soils comes from roots. For example, some studies have reported that SOM decomposition may be $380 \%$ greater in soils with roots compared to unplanted soils (positive rhizosphere priming effects; RPE) (Cheng et al., 2014). Accordingly, the magnitude of RPE may control C fluxes at the ecosystem level and influence ecosystem feedbacks to climate (Cheng et al., 2014; Finzi et al., 2015).

The explanation for most of the reported positive RPE is microbial activation, i.e. the stimulation of growth and activity induced by root-derived substrates. Microbes utilize 
this energy subsidy to produce extracellular enzymes (exoenzymes) that enhance the release of nutrients from SOM (Blagodatskaya and Kuzyakov, 2008). While microbes benefit from the nutrients released through enhanced decomposition, plants may benefit too - suggesting that RPE may be an evolutionary stable strategy (Cheng et al., 2014).

Living roots release numerous available low molecular weight substrates such as sugars, carboxylic acids and amino acids throughout the soil profile and over the course of the growing season (Nguyen, 2003; Jones et al., 2009). These substrates are not homogeneously distributed along the root segments but are rather released in distinct areas, mainly at the root tips (McDougall and Rovira, 1970; Nguyen, 2003; Dennis et al., 2010; Pausch and Kuzyakov, 2011). For this reason, root morphology (e.g. lateral root formation, number of root tips, root hair formation) may largely impact exudation (Nguyen, 2003), and may, hence, be decisive for rhizosphere priming effects. The root morphology, in turn, is mainly controlled by the nutrient availability in the soil since changes in root architecture can alter the capacity of plants to take up nutrients (López-Bucio et al., 2003). Several strategies have been developed by plants to increase the uptake of limited nutrients from the soil. An efficient strategy to acquire limited nutrients is the production of root hairs, which could differ in numbers, density and length between plant species depending on the kind of nutrients and nutrient availability in the soil (Jungk, 2001). The substantial contribution of root hairs to plant nutrition and accompanied therewith nutrient shortages in the rhizosphere and high energy supply to microbes through exudation, as well as direct and indirect enhancement of enzyme activities (Spohn and Kuzyakov, 2014) may be crucial for rhizosphere priming effects. A barley mutant lacking root hairs completely was discovered by Gahoonia et al. (2001). This mutant enabled us to study the role of root hairs for rhizosphere priming effects. 
In the present experiment a barley wild type with root hairs and the root hairless mutant were grown under controlled conditions. Rhizosphere priming effects, i.e. changes in the rate of SOM decomposition, were indicated by an increase or decrease of $\mathrm{SOM}$-derived $\mathrm{CO}_{2}$ production in planted compared to an unplanted soil. By continuously labeling plants with ${ }^{13} \mathrm{C}$-depleted $\mathrm{CO}_{2}$, we were able to differentiate root-derived $\mathrm{CO}_{2}$ from SOM-derived $\mathrm{CO}_{2}$ and calculate $\mathrm{RPE}$ as the difference in SOM-derived $\mathrm{CO}_{2}$ between planted and unplanted soils. To investigate the influence of plant age, the soil $\mathrm{CO}_{2}$ efflux was trapped at two plant growth stages of (tillering and head-emergence). Microbial parameters (microbial biomass $\mathrm{C}$ and nitrogen $(\mathrm{N})$, enzyme activities) were analyzed to assess changes of microbial activities.

We hypothesize that the rhizosphere priming effect depends on root morphology. More specifically, a better nutrient acquisition of the wild type with root hairs through a higher total root surface area resulted in a larger plant biomass production, thus, leading to higher exudation and higher positive RPE. We also expect that the higher the positive priming is the more active are exoenzymes responsible for the decomposition of more stable substrates. Plant age is known to play an important role for the intensity of priming (Fu and Cheng, 2002; Pausch et al., 2013). Due to different growth pattern and nutrient demands, we hypothesize that plant age influences rhizosphere priming on SOM decomposition differently for the hairless barley mutant and the barley wild type with root hairs.

\section{Material and Methods}

\subsection{Experimental Setup}

Two barley (Hordeum vulgare L.) types, a wild type (cv. optic; WT) and a roothairless mutant called bald root barley (brb, Gahoonia et al., 2001, Fig. 1), were grown in a greenhouse and were continuously labeled with ${ }^{13} \mathrm{C}$-depleted $\mathrm{CO}_{2}$ (Cheng 
and Dijkstra, 2007). The plants were exposed to the tracer from the emergence of the first leaf till the end of the experiment. Briefly, a constant $\mathrm{CO}_{2}$ concentration of $400 \pm 5$ ppm and a constant $\delta^{13} \mathrm{C}$ value of about $-18 \%$ was maintained inside the greenhouse over the course of the experiment by regulating the flow of ${ }^{13} \mathrm{C}$-depleted $\mathrm{CO}_{2}(99.9 \%$ $\mathrm{CO}_{2}, \delta^{13} \mathrm{C}$ of $-38 \%$ ) from a tank and setting $\mathrm{CO}_{2}$-free air flow rate proportional to the leakage rate $(300 \mathrm{~L} / \mathrm{min})$ of the greenhouse (Zhu and Cheng, 2012; Pausch et al., 2013). The $\mathrm{CO}_{2}$-free air was produced from compressed air passed through six soda lime columns (20 cm diameter, $200 \mathrm{~cm}$ length) filled with approximately $40 \mathrm{~kg}$ soda lime (pellets made of $\mathrm{NaOH}$ and $\mathrm{Ca}(\mathrm{OH})_{2}$ mixture) each. The $\mathrm{CO}_{2}$-free air flow was set at $120 \mathrm{~L} / \mathrm{min}$. The $\mathrm{CO}_{2}$ concentration inside the greenhouse was continuously monitored by an infra-red gas analyzer (Model LI-820, Li-COR, Lincoln, NE, USA) and stabilized at $400 \pm 5 \mathrm{ppm}$ by computer-controlled $\mathrm{CO}_{2}$ injection from the tank. $\mathrm{A}$ fan was used to ensure a uniform distribution of the $\mathrm{CO}_{2}$ inside the greenhouse. For the duration of the experiment, the $\delta^{13} \mathrm{C}$ value of the greenhouse air was measured every three days during the light period by pumping air through a glass airstone immersed in $50 \mathrm{~mL}$ of $0.5 \mathrm{M} \mathrm{NaOH}$ solution. The $\mathrm{CO}_{2}$ trapping efficiency was nearly 100\% as checked by an infra-red gas analyzer (Model LI-6262, Li-COR, Lincoln, NE, USA). An aliquot of the sample was precipitated with $\mathrm{SrCl}_{2}$ as $\mathrm{SrCO}_{3}$ using the method described by Harris et al. (1997) and analyzed for $\delta^{13} \mathrm{C}$ (relative to PDB standard) using a PDZ Europa ANCA-GSL elemental analyzer interfaced to a PDZ Europa 20-20 isotope ratio mass spectrometer (Sercon Ltd., Cheshire, UK). The mean $\delta^{13} \mathrm{C}$ value of the $\mathrm{CO}_{2}$ in the greenhouse air was $-18.2 \pm 0.3 \%$.

The two barley types were grown in PVC pots $(15 \mathrm{~cm}$ diameter, $40 \mathrm{~cm}$ height, equipped with an inlet tube at the bottom for aeration and soil $\mathrm{CO}_{2}$ trapping). A nylon bag filled with $\sim 1500 \mathrm{~g}$ sand was placed at the bottom of each PVC pot to improve air circulation. Each pot was filled with about $7 \mathrm{~kg}$ sieved $(<2 \mathrm{~mm})$ soil. The soil was 
taken from the plough horizon (top $20 \mathrm{~cm}$ ) of a sandy loam (Mollisol) from a farm on the campus reserves of the University of California, Santa Cruz. The soil contained $1.18 \pm 0.01 \%$ organic $\mathrm{C}$ and $0.13 \pm 0.001 \% \mathrm{~N}$, had $\delta^{13} \mathrm{C}$ and $\delta^{15} \mathrm{~N}$ values of $26.45 \pm 0.07 \%$ and $7.12 \pm 0.02 \%$, respectively, and a $\mathrm{pH}$ value of 5.8 . All filled pots were wetted to $20 \%$ gravimetric soil moisture content (equivalent of $80 \%$ of the water holding capacity) with deionized water.

For each barley type, 10 pots were set up. In addition, 8 unplanted pots (unplanted soil; US) were prepared (in total 28 pots). The seeds were presoaked overnight and 6-8 barley seeds were planted per pot. The inlet tube at the bottom of each pot was connected to an aquarium pump to aerate the pots. This was done 2 times during the dark period to avoid contamination of the growth chamber $\delta^{13} \mathrm{C}$ signal with that of soil-derived $\mathrm{CO}_{2}$ during the assimilation period.

The soil moisture content was measured gravimetrically and adjusted daily to $80 \%$ of the water holding capacity. To maintain homogeneous soil moisture and good soil structure, water was added through perforated tubes buried at the center of the pot (inner diameter $0.32 \mathrm{~cm}$, total length $20 \mathrm{~cm}$, buried length $10 \mathrm{~cm}$ ). The location of the pots in the greenhouse was changed weekly by mixing them randomly to guarantee similar growing conditions for the plants. The day time air temperature inside the greenhouse was maintained at $23^{\circ} \mathrm{C}$ by two air conditioning units. The night time temperature was kept above $17^{\circ} \mathrm{C}$. Artificial lighting (1100W lights, P.L. Light Systems, Beamsville, ON) was used to ensure an adequate light intensity throughout the experiment. The light intensity was kept above $900 \mathrm{~W} \mathrm{~m}^{-2}$. The photoperiod was set from $4: 30 \mathrm{AM}$ to $4: 30 \mathrm{PM}$. The relative air humidity was kept at $45 \%$ by a dehumidifier (Kenmore Elite 70 pint, Sears, Chicago, IL, USA).

(Figure 1) 


\subsection{Measurements}

\subsubsection{Soil $\mathrm{CO}_{2}$ efflux}

Soil $\mathrm{CO}_{2}$ efflux from each pot was measured at two growth stages of barley, 29-30 days after planting (DAP) at tillering (T1) and 64-65 DAP at head-emergence (T2), by using a closed-circulation $\mathrm{CO}_{2}$ trapping system (Cheng et al., 2003; Pausch et al., 2013). Prior to each $\mathrm{CO}_{2}$ trapping the pots were sealed with non-toxic silicone rubber (Gl-1000, Silicones Inc., NC, USA) added directly to the soil surface.

Soil $\mathrm{CO}_{2}$ trapping was performed on 4 replicates each of the unplanted soil, and the barley with and without root hairs at $\mathrm{T} 1$. At $\mathrm{T} 2, \mathrm{CO}_{2}$ was trapped from 6 replicates of planted pots and 4 replicates of unplanted pots. Shortly before $\mathrm{CO}_{2}$ trapping, the $\mathrm{CO}_{2}$ inside the pots was removed by circulating the isolated air through a soda lime column ( $3 \mathrm{~cm}$ diameter, $50 \mathrm{~cm}$ length) for $40 \mathrm{~min}$. Then $\mathrm{CO}_{2}$ produced in the sealed pots was trapped for $24 \mathrm{~h}$ in $400 \mathrm{ml}$ of $0.5 \mathrm{M} \mathrm{NaOH}$ solution. Four blanks were included to correct the total inorganic $\mathrm{C}$ content for possible contamination from carbonate in the $\mathrm{NaOH}$ stock solution and from sample handling (Cheng et al., 2003; Pausch et al., 2013). An aliquot of each $\mathrm{NaOH}$ solution was analyzed for total inorganic carbon using a Shimadzu TOC-5050A Total Organic Carbon Analyzer. Another aliquot was precipitated as $\mathrm{SrCO}_{3}$ (Harris et al., 1997) and analyzed for $\delta^{13} \mathrm{C}$ by means of a continuous flow isotope ratio mass spectrometer as described above.

\subsubsection{Shoot, root and soil analyses}

After each $\mathrm{CO}_{2}$ sampling the pots were destructively harvested. The shoots were cut at the base. The soil of each pot was pulled out and the roots were separated by hand-picking. Subsamples of about $1 \mathrm{~kg}$ soil were stored in a freezer $\left(-18^{\circ} \mathrm{C}\right)$ until further analysis. Shoots, root, and soil samples were dried at $60^{\circ} \mathrm{C}$ for 3 days, 
weighed, ground in a ball mill and measured for $\delta^{13} \mathrm{C}$ and $\delta^{15} \mathrm{~N}$ using a Carlo Elba 1108 elemental analyzer interfaced to a Thermo-Finningan Delta Plus XP isotope ratio mass spectrometer at the Isotope Facility of University of California-Santa Cruz. Dissolved $\mathrm{N}(\mathrm{DN})$ which is extractable with $\mathrm{K}_{2} \mathrm{SO}_{4}$ was determined as described below (2.2.3). Extractable phosphorus (bioavailable inorganic ortho-phosphate) was determined on dried and ground soil samples by the Bray-Method at the Analytical Laboratory, University of California, Davis (http://anlab.ucdavis.edu/).

\subsubsection{Microbial biomass $\mathrm{C}$ and $\mathrm{N}$}

Soil microbial biomass $C(\mathrm{MBC})$ and soil microbial biomass $N(\mathrm{MBN})$ were determined on all soil samples by the chloroform-fumigation-extraction method described by Vance et al. (1987) with the modification that fumigated and nonfumigated soil samples $(7.5 \mathrm{~g})$ were extracted for 1 hour with $30 \mathrm{~mL}$ of $0.05 \mathrm{M} \mathrm{K}_{2} \mathrm{SO}_{4}$ solution. The samples were filtered (Quantitative Paper FT-3-101-09, Sartorius) and the extracts were analyzed for total organic $C$ and $N$ by means of a multi $N / C$ analyzer (multi N/C analyzer 2100S, Analytik Jena). Total $\mathrm{N}$ content of the nonfumigated extracts were used as a measure of available $\mathrm{N}$. The difference between the extracts of fumigated and non-fumigated samples gave the amount of chloroformlabile $\mathrm{C}$ and $\mathrm{N}$ (hereafter referred to as $\mathrm{MBC}$ and $\mathrm{MBN}$ ). We noted that these values did not correspond to total amount of MBC and MBN as the extraction efficiency was not taken into account. Reported conversion factors kec (or ken for $\mathrm{N}$ ) ranged from less than 0.2 to 0.45 among different soils (Wu et al., 1990; Dictor et al., 1998; Bailey et al., 2002). Thus, for the purpose of comparing treatment effects and avoiding biases of conversion factors, the data presented in this study were not corrected by conversion factor. 


\subsubsection{Enzyme assays}

To determine the activities of the enzymes $\beta$-cellobiohydrolase (exo-1,4- $\beta$-glucanase, EC 3.2.1.91), $\beta$-glucosidase (EC 3.2.1.21), acid phosphatase (EC 3.1.3.2), $\beta$ xylosidase (EC 3.2.2.27), leucin-aminopeptidase (LAP) (EC 3.4.11.1), and N-acetyl$\beta$-glucosaminidase (chitinase, EC 3.2.1.52), we used 4-methylumbelliferyl- $\beta$-Dcellobioside, 4-methylumbelliferyl- $\beta$-D-glucopyranoside, 4-methylumbelliferylphosphate, 4-methylumbelliferyl-7- $\beta$-D-xylopyroniside, L-leucine-7amino-4methylcoumarin hydrochloride and 4-methylumbelliferyl $\mathrm{N}$-acetyl- $\beta$-D-glucosaminide, respectively. The soil suspension was dispersed by an ultrasonic disaggregator (50 J $\mathrm{s}^{-1}$ for $120 \mathrm{~s}$ ) after addition of half a gram of soil to $50 \mathrm{ml}$ sterile water in autoclaved jars (De Cesare et al., 2000). While stirring the soil suspension $50 \mu \mathrm{l}$ aliquots were withdrawn and dispensed in 96-well microplates (Brand pureGrade, black). Buffer (80 $\mathrm{ml}$ ) was added (0.1 M MES buffer, $\mathrm{pH} 6.1$ for carbohydrases and phosphatase, 0.05 M TRIZMA buffer, pH 7.8 for leucine-aminopeptidase) (Marx et al., 2001; 2005; Loeppmann et al., 2016).

We added $100 \mu \mathrm{l}$ of series concentrations of substrate solutions $(20,40,60,80,100$, $200,400 \mu \mathrm{mol}$ substrate $\mathrm{g}^{-1}$ soil) to the wells and kept the temperature at $21^{\circ} \mathrm{C}$. The micro-plates were agitated and measured fluorometrically (excitation $360 \mathrm{~nm}$; emission $450 \mathrm{~nm}$ ) after $1 \mathrm{~h}, 2 \mathrm{~h}$, and $3 \mathrm{~h}$ incubation with an automated fluorometric plate-reader (Wallac 1420, Perkin Elmer, Turku, Finland). Fluorescence was converted into an amount of MUB (4-methylumbelliferone) or AMC (7-amino-4methylcoumarin), according to specific standards, which had been prepared in subsamples from the various soil suspensions.

\subsection{Calculations}


The contribution of $\mathrm{CO}_{2}$ derived from SOM decomposition (Csom-DeRived, $\mathrm{mg} \mathrm{C} \mathrm{kg}^{-1}$ soil day $^{-1}$ ) to total soil respiration was calculated using a linear two-source isotopic mixing model:

$$
\begin{aligned}
& C_{\text {SOM-DERIVED }}=C_{\text {TOTAL }} \cdot \frac{\delta^{13} C_{\text {TOTAL }}-\delta^{13} C_{\text {ROOT-DERIVED }}}{\delta^{13} C_{\text {SOM-DERIVED }}-\delta^{13} C_{R O O T-D E R I V E D}} \\
& C_{\text {ROOT-DERIVED }}=C_{\text {TOTAL }}-C_{\text {SOM-DERIVED }}
\end{aligned}
$$

where СтотAL is the total $\mathrm{CO}_{2}$ efflux of the planted soil $\left(\mathrm{mg} \mathrm{C} \mathrm{kg}^{-1}\right.$ soil day-1) and $\delta^{13} \mathrm{C}$ total the corresponding $\delta^{13} \mathrm{C}$ value $(\%) . \delta^{13} \mathrm{Csom}$-Derived is the $\delta^{13} \mathrm{C}$ value of $\mathrm{CO}_{2}$ from SOM decomposition measured in the unplanted soils $(\%)$. Note, as priming may promote the decomposition of specific compounds of SOM with varying $\delta^{13} \mathrm{C}$, the $\delta^{13}$ Csom-DeRIVed could slightly be biased.

CROOT-DeRIVEd is the root-derived $\mathrm{CO}_{2}$ in the planted soils $\left(\mathrm{mg} \mathrm{C} \mathrm{kg}^{-1}\right.$ soil day-1) with

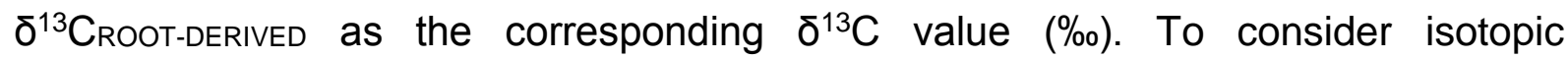
fractionation, we accounted for ${ }^{13} \mathrm{C}$ differences between the isotopic composition of roots and that of root-derived $\mathrm{CO}_{2}$ (Pausch et al., 2013). The fractionation factor ( $f$ ) was taken from Zhu and Cheng (2011) and was $-0.87 \%$. This fractionation factor was measured for wheat (Triticum aestivum) and was chosen since barley and wheat are both belonging to the Poaceae family and are both monocotyledons with similar properties. Root-derived $\mathrm{CO}_{2}$ was calculated based on the assumption of an equal isotopic fractionation for the barley wild type and the mutant.

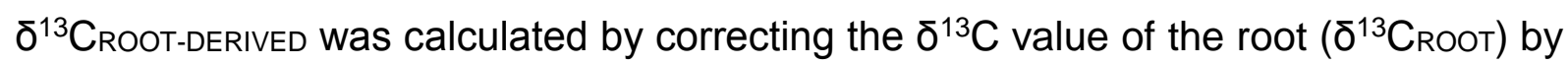
a fractionation factor $(f)$ : 
$\delta^{13} C_{\text {ROOT-DERIVED }}=\delta^{13} C_{\text {ROOT }}+f$

(Table 1)

The RPE on SOM decomposition was calculated by subtracting the $\mathrm{CO}_{2}$ flux of the unplanted soil (CSOM-DERIVED (US)) from the SOM-derived $\mathrm{CO}_{2}$ flux of the planted soil (Csom-derived (WT, brb)).

$R P E=C_{S O M-D E R I V E D}(W T, b r b)-C_{S O M-D E R I V E D}(U S)$

The RPE was related to total root biomass ( $\mathrm{gDW}$ ) as well as expressed as percentage of basal respiration of the unplanted soil.

\subsection{Statistics}

The values presented in the figures and tables are given as means \pm standard errors. A one-way analysis of variance (ANOVA) was conducted to test for significant differences in all measured data between the unplanted soil, and barley with and without root hairs by calculating the ANOVA separately for each sampling date. The significance of differences between individual means was obtained by a post hoc unequal N HSD test. Moreover, rhizosphere priming values were tested for significant deviation from zero by a t-test. All statistical analyses were performed with the statistical package STATISTICA for Windows (version 7.0; StatSoft Inc., OK, USA). For enzyme analyses, we used a non-linear regression (Michaelis-Menten kinetics) to estimate the kinetic parameter $V_{\max }$ (Marx et al., 2001). Each soil sample was measured as an analytical triplicate. The kinetic parameters were fitted by minimizing the least-square sum using GraphPad Version 6 software (Prism, USA). Parameter 
optimization was restricted to the applied model equation as indicated by maximum values of statistic criteria: $r^{2}$. Outliers were identified by the ROUT method, based on the False Discovery Rate (FDR) (Motulsky and Brown, 2006). A multiple t-test was applied to test for differences in enzyme activities between the unplanted soil, and the barley with and without root hairs and between T1 and T2. Statistical significance was determined using the Holm-Sidak method $(P \leq 0.05)$.

\section{Results}

\subsection{Plant biomass and $\delta^{13} \mathrm{C}$ and $\delta^{15} \mathrm{~N}$ values}

The main difference between the two barley types was the production of plant biomass; shoots and roots. The mutant (brb), completely lacking root hairs, produced higher shoot biomass during the tillering stage ( $\mathrm{T} 1)$ but root biomass was not significantly different compared to the wild type (WT). However, at head-emergence stage (T2) root biomass of the mutant was reduced compared to the wild type (WT) (Table 2).

At $\mathrm{T} 1, \mathrm{C}$ and $\mathrm{N}$ contents of shoots were on average $34.3 \pm 0.4 \%$ and $6.1 \pm 0.1 \%$, respectively. At T2 a higher $\mathrm{C}$ content of $38.2 \pm 0.4 \%$ was measured while the $\mathrm{N}$ content decreased to $1.7 \pm 0.1 \%$ compared to $\mathrm{T} 1$. This led to a much higher $\mathrm{C} / \mathrm{N}$ ratio at T2 compared to T1 (Table 2). Similarly, the $\mathrm{C}$ content of roots was higher at T2 (33.6 $\pm 1.1 \%)$ compared to $\mathrm{T} 1(22.1 \pm 2.0 \%)$. The $\mathrm{N}$ content of roots, however, was similar between the two sampling times. The $\mathrm{C} / \mathrm{N}$ ratio of roots increased from $13.9 \pm 0.6$ at $\mathrm{T} 1$ to $25.3 \pm 1.4$ at $\mathrm{T} 2$.

The plants were successfully labeled with ${ }^{13} \mathrm{C}$-depleted $\mathrm{CO}_{2}$ as shown by the $\delta^{13} \mathrm{C}$ values of shoots and roots (Table 2). The $\delta^{13} \mathrm{C}$ value of shoots was $-41.4 \pm 0.1 \%$ at T1 which was lower than at T2 $\left(-39.3 \pm 0.3 \%\right.$ ). The $\delta^{13} \mathrm{C}$ value of roots did not differ 
between $\mathrm{T} 1$ and $\mathrm{T} 2$. Interestingly, the $\delta^{15} \mathrm{~N}$ value of roots increased between $\mathrm{T} 1$ and T2 and was about 2.6\% higher at T2 (Table 2).

(Table 2)

\subsection{Soil $\mathrm{N}$ and $\mathrm{P}$ contents}

Available P did not differ between planted and unplanted soils likely because of the high $\mathrm{P}$ availability of the soil used in this study (Table 3). However, nutrient uptake by plants led to lower dissolved $N(D N)$. The $D N$ content was reduced by $\sim 46 \%$ in planted soil compared to the unplanted soil at tillering. At head-emergence stage, only $14 \%$ of the initial DN content (unplanted soil at T1) remained in the planted soils (Table 3).

(Table 3)

\subsection{Microbial biomass $\mathrm{C}$ and $\mathrm{N}$ and enzyme activities}

MBC and MBN (chloroform-labile $\mathrm{C}$ and $\mathrm{N}$ ) was similar between the unplanted soil, and the barley with and without root hairs (Table 3). However, at the heademergence stage of plant growth (T2) MBC and MBN increased for both barley types compared to the tillering stage ( $\mathrm{T} 1)$.

At tillering stage, the wild type had lower activities of $\beta$-glucosidase, $\beta$ cellobiohydrolase (not significant), and acid phosphatase, while the activity of $\beta$ xylosidase and chitinase were higher compared to the unplanted soil (Fig. 2). In contrast, the activities of $\beta$-glucosidase, $\beta$-cellobiohydrolase, and LAP did not differ between brb and the unplanted soil, but a higher activity of $\beta$-xylosidase and acid phosphatase was measured. At head-emergence stage, both barley types induced 
lower activity rates of $\beta$-glucosidase and LAP (yet not significant for brb), while the activities of $\beta$-xylosidase and chitinase increased through planting. $\beta$ cellobiohydrolase and acid phosphatase activities of the planted soils were similar to that of the unplanted soil at T2.

(Figure 2)

\section{4 $\mathrm{CO}_{2}$ efflux partitioning}

Total soil $\mathrm{CO}_{2}$ efflux was influenced by planting and by the barley genotype as well as by sampling time. At T2 all planted soils showed higher total soil $\mathrm{CO}_{2}$ efflux (sum of SOM- and root-derived $\mathrm{CO}_{2}$ ) compared to the unplanted soils (Fig. 3).

SOM-derived $\mathrm{CO}_{2}$ was higher for WT $\left(29.2 \pm 0.6 \mathrm{mg} \mathrm{C} \mathrm{kg}^{-1}\right.$ soil day-1) compared to brb (12.5 $\pm 1.8 \mathrm{mg} \mathrm{C} \mathrm{kg}^{-1}$ soil day ${ }^{-1}$ ) at T1 (Fig. 3, top). Moreover, at T2 both barley types had higher SOM-derived $\mathrm{CO}_{2}\left(24.3 \pm 3.0 \mathrm{mg} \mathrm{C} \mathrm{kg}^{-1}\right.$ soil day ${ }^{-1}$ for WT and $43.8 \pm 9.7 \mathrm{mg}$ $\mathrm{C} \mathrm{kg}^{-1}$ soil day ${ }^{-1}$ for brb) compared to the unplanted soil $\left(14.2 \pm 0.3 \mathrm{mg} \mathrm{C} \mathrm{kg}^{-1}\right.$ soil day 1). However, this was only statistically significant $(P>0.05)$ for the root-hairless mutant. While SOM-derived $\mathrm{CO}_{2}$ remained relatively constant for the unplanted soil and the WT between $\mathrm{T} 1$ and T2, the brb showed higher SOM-derived $\mathrm{CO}_{2}$ at T2.

Root-derived $\mathrm{CO}_{2}$ consists of $\mathrm{CO}_{2}$ released from root respiration per se and of $\mathrm{CO}_{2}$ released through microbial decomposition of rhizodeposits. Root-derived $\mathrm{CO}_{2}$ positively correlates with root biomass $\left(R^{2}=0.99\right.$, data not shown) (Pausch et al., 2013). At tillering, root-derived $\mathrm{CO}_{2}$ did not differ between the barley wild type and the mutant. However, root-derived $\mathrm{CO}_{2}$ increased at head-emergence for both barley types with increasing root biomass (Fig. 3 (bottom), Table 2). Moreover, the lower root biomass of the brb at T2 compared to WT is reflected in a slight, but not significant, lower root-derived $\mathrm{CO}_{2}$. 
On a root dry weight basis, root-derived $\mathrm{CO}_{2}$ was similar in the two barley types and between sampling dates (Fig. 3, inlet). However, there was a trend of less rootderived $\mathrm{CO}_{2}$ at head-emergence (Fig. 3, inlet).

(Figure 3)

\subsection{Rhizosphere priming effect}

During the early stage of plant growth (T1), rhizosphere priming was largely influenced by the barley genotype. While SOM decomposition was increased for the wild type by $69 \%$ compared to the unplanted soil (difference to zero $\mathrm{P}=0.002$ ), it decreased for the root-hairless barley by $28 \%$ (difference to zero $\mathrm{P}=0.051$; Fig. 4 , right $y$-axis). At the head-emergence stage (T2), both barley types showed positive priming effects with even higher intensity under the mutant. Rhizosphere priming was enhanced for the wild type compared to the unplanted soil by $72 \%$ (difference to zero $P=0.020)$. The highest positive priming effect was measured for the barley mutant lacking root hairs, amounting to $209 \%$ of the unplanted soil (difference to zero $\mathrm{P}=0.055)$.

To account for root properties effects, a specific RPE was calculated by relating total primed C to root biomass (Fig. 4, left y-axis). The specific RPE was highest for the wild type at the early stage of plant growth with $47.9 \pm 1.1 \mathrm{mg} \mathrm{C} \mathrm{g}^{-1}$ root day-1 (difference to zero $P=0.096$ ). A negative priming effect for the brb was measured at T1 with $-22.2 \pm 8.5 \mathrm{mg} \mathrm{C} \mathrm{g}^{-1}$ root day ${ }^{-1}$ (difference to zero $\mathrm{P}=0.055$ ). At the heademergence stage (T2) the WT showed with $5.7 \pm 2.0 \mathrm{mg} \mathrm{C} \mathrm{g}^{-1}$ root day ${ }^{-1}$ (difference to zero $P=0.035)$, a lower specific RPE than during tillering (T1). In contrast, the barley mutant shifted from negative priming at T1 to a positive RPE at T2 $(28.2 \pm 9.7 \mathrm{mg} \mathrm{C} \mathrm{g}$ ${ }^{1}$ root day ${ }^{-1}$; difference to zero $P=0.062$ ). 
(Figure 4)

\section{Discussion}

During the tillering stage of plant growth, SOM decomposition was enhanced (positive priming) in soils with the barley wild type by $69 \%$ compared to the basal respiration of the unplanted soil. The data was within the range of priming results published for wheat, another monocotyledon plant from the Poaceae family. Wheat showed positive priming effects ranging from $42 \%$ of the unplanted soil ( 28 days old wheat) (Cheng and Johnson, 1998; Cheng et al., 2014) to 75\% for 30 days old wheat (Pausch et al., 2013). Positive priming effects could be explained by the 'microbial activation hypothesis' (Kuzyakov, 2002; Cheng and Kuzyakov, 2005), which assumes that the activity and growth of microorganisms is enhanced through metabolizing labile substrates (e.g. root exudates), further leading to an accelerated SOM turnover. In the presence of labile plant $\mathrm{C}$ microbes start decomposing SOM to acquire N ('Microbial nitrogen mining' Crain et al., 2007).

Interestingly, the barley mutant lacking root hairs showed a complete opposed effect on SOM turnover. SOM decomposition was reduced by $28 \%$ compared to the unplanted soil; hence, the brb induced negative priming at the tillering stage. As both barley types produced same amounts of roots at the tillering stage, our result point to root morphology (here the presence or absence of root hairs) as a main determinant for RPE. Negative priming effects were observed in short-term experiments (Cheng et al., 2014) and were explained either by 1) 'Preferential substrate utilization' (PSU), i.e., microorganisms, not limited in $\mathrm{N}$, can switch from the decomposition of SOM to the decomposition of easily available rhizodeposits or by 2) 'Microbial competition hypotheses'. The latter suggests that microbes and plants compete for nutrients and 
thus, microbial growth decreases, thereby, depressing SOM decomposition (Kuzyakov, 2002; Cheng and Kuzyakov, 2005). At tillering, when mineral nutrients were still abundant, the activity of extracellular enzymes measured in soils with the root-hairless mutant did not differ or even increased (B-xylosidase, acid phosphatase) compared to the unplanted soil. This may point to PSU.

The present study suggests that at the tillering stage, root morphology plays a major role for rhizosphere priming effects. It is likely, that the extension of the rhizosphere by root hairs accelerated SOM decomposition.

At the head-emergence stage, both barely types induced positive rhizosphere priming effects. When referred to the unplanted soil, the wild type primed $72 \%$, while the brb increased SOM-decomposition by $209 \%$ compared to the unplanted soil. In a recent study Mwafulirwa et al. (2016) investigated barley genotypes and reported negative priming at day 19 after planting while all genotypes induced positive priming after 27 days of growth when nutrients are becoming scarce. Overall, a higher root biomass per pot ( 7 times higher for WT between T1 and T2, and 3 times higher for brb) at increasing $\mathrm{N}$ limitation (about 7 times as lower at T2 as the initial value of US at T1) triggers the positive priming effects at T2 in the present study. Since the dissolved $\mathrm{N}$ is highly reduced at $\mathrm{T} 2$, it is probable that microorganisms start mining for $\mathrm{N}$ to meet their $\mathrm{N}$ demand and thus, decompose SOM more intensively. This effect is clearly indicated by the $\delta^{15} \mathrm{~N}$ values of the plants. $\delta^{15} \mathrm{~N}$ values increase with SOM stabilization (Kramer et al., 2003), hence, more stabilized SOM pools are likely enriched in ${ }^{15} \mathrm{~N}$. For both barley types the $\delta^{15} \mathrm{~N}$ values of roots were higher at the head-emergence stage indicating a higher $\mathrm{N}$ gain from more stabilized SOM sources and hence positive rhizosphere priming effects.

Plant phenology plays a major role for the magnitude of rhizosphere priming effects. The specific rhizosphere priming (RPE per root dry weight) was reduced for the 
barley wild type when comparing between the tillering and head-emergence growth stages. A reduction of RPE at later growth stages has also been reported for wheat after flowering (Cheng et al., 2003). Young plants translocate higher proportions of assimilated C belowground than older plants (reviewed by Nguyen, 2003). Rootderived $\mathrm{CO}_{2}$ per unit of root mass was higher at tillering compared to heademergence (yet not significant).

Moreover, the $\mathrm{C} / \mathrm{N}$ ratio of roots was about twice as high at the head-emergence stage compared to the tillering and $\mathrm{C} / \mathrm{N}$ ratios of shoots were even three to four times higher when comparing the two sampling dates. Thus, the large $N$ demand of the plant is likely to induce the positive priming effects measured at T2. At the heademergence stage, when nutrients are becoming scarce, the barley mutant without root hairs probably suffered from the inefficiency in nutrient uptake as indicated by a lower root biomass compared to the wild type. However, in contrast to the specific RPE of the wild type, which was reduced between the sampling dates most likely because of reduced allocation of assimilates belowground (Nguyen, 2003), the root hairless mutant showed the opposed effect. Specific RPE increased between the tillering and head-emergence stages to positive values, and even exceeds the RPE of the wild type. The inefficiency of the hairless mutant in nutrient uptake may have increased rhizodeposition due to a faster decay of roots, induced by insufficient supply of nutrients.

Root hairs may contribute $70-90 \%$ to total root surface area (Bucher, 2007), and therefore root hairs are crucial for nutrient uptake of the plant. Especially the uptake of phosphorus, which is highly immobile in soils, is promoted by root hairs. Phosphorus is quantitatively the second most limiting nutrient for plant growth after $\mathrm{N}$ (Lambers et al., 2006). Gahoonia and Nielsen (2003) showed a much stronger Pdepletion zone around the root hairs of a barley wild type than for the root hairless 
mutant. Under $\mathrm{P}$ limitation, higher phosphatase activity in the soil was shown to increase the transformation of organic phosphates into available forms (Gahoonia et al., 2001; Paterson 2003; Olander and Vitousek, 2000). In our study, the activity of acid phosphatase at tillering is lower for the wild type but higher for the mutant without root hairs compared to the unplanted soil. This pattern diminished at the head-emergence stage where phosphatase activity did not differ between unplanted soil and barley with and without root hairs. These contradictory results are likely explained by the high P availability of our soil.

The activity of the C-cycling associated enzymes, $\beta$-glucosidase and $\beta$ cellobiohydrolase, responsible for the decomposition of relatively labile $\mathrm{C}$ molecules (simple sugars, starch, cellulose), was lower for the wild type compared to the unplanted soil and the root hairless mutant at T1. At T2, both barley types showed lower $\beta$-glucosidase activities compared to the unplanted soil (yet not significant for brb) indicating lower microbial investments in C-cycling enzymes (Allison et al., 2011). Planting increased the activity of B-xylosidase and chitinase at both growth stages. The decomposition of the hemicellulose xylan, a major constituent of litter, is catalyzed by B-xylosidase into more available carbohydrates (Sinsabaugh and Moorhead., 1994; Loeppmann et al., 2016). The chitinase (N-acetyl-glucosaminidase) degrades chitin (unbranched polymer of N-acetyl-D-glucosamine), which is found in bacterial and fungal cells (Beier and Bertilsson, 2013). Chitin is an important source of organic $\mathrm{N}$ in soil, as it is one of the most abundant polymers on earth and contains about 6\% N in relatively recalcitrant form (Ekenler and Tabatabai, 2002; Duo-Chuan, 2006; Kelly et al., 2011). In N-poor microsites, i.e. at low concentrations of mineral N, the production of $\mathrm{N}$-acquiring exoenzymes such as amino-peptidases (e.g. LAP) and chitinases (e.g. $\mathrm{N}$-acetyl-glucosaminidase) are stimulated to obtain more $\mathrm{N}$ from organic forms (Olander and Vitousek, 2000; Weintraub and Schimel, 2005; Kelly et 
al., 2011). When mineral $\mathrm{N}$ is becoming scarce, microbes decompose more labile forms of $\mathrm{N}$-containing organic matter first because less energy is required (Kelly et al., 2011). Thereafter, according to microbial life strategy, several microbial guilds may shift their enzyme production (Schimel and Schaeffer, 2012) from enzymes responsible for degradation of relatively labile substrate (e.g. LAP, cleaving of peptide bonds in proteins) to enzymes decomposing relatively recalcitrant substrates (e.g. chitinase, hydrolysis of chitooligosaccharides into $\mathrm{N}$-acetylglucosamine) to meet the metabolic $\mathrm{N}$ demand (Kelly et al., 2011). In this experiment, the LAP activity was reduced for both barley types between T1 and T2 (statistically significant only for WT). In contrast, chitin is produced by microorganisms and chitinase activity was shown to be enhanced by the presence of the rhizosphere (Geisseler et al., 2010). Microbial biomass was higher at T2 than at T1 for the planted soils. Thus, a higher microbial growth and death led to the release of chitin into the soil, which induced the high chitinase activities of both barley types at T2. The shift from enzymes degrading labile substrates to enzymes that decompose more recalcitrant forms of $\mathrm{N}$ is a strong indication for priming effects on SOM decomposition.

\section{Conclusions}

The present study suggests that rhizosphere priming effects are intimately linked to root morphology, e.g. root hairs. While the barley wild type with root hairs induced positive priming during tillering (69\% above unplanted soil), the mutant without root hairs suppressed SOM decomposition by $28 \%$. At head-emergence, microbial biomass increased for both planted soils compared to the tillering stage; and both barley types showed positive priming effects (accelerated SOM decomposition). The SOM decomposition rate under the hairless mutant barley even exceeds that of the wild type despite lower root biomass (72\% priming for the wild type, 209\% priming for 
the mutant). In cases of positive priming, chitinase and B-xylosidase activities increased suggesting accelerated decomposition of stable SOM. Future research emphasis should be placed on potential mechanisms linking root morphology and microbial activity with rhizosphere priming effects.

\section{Acknowledgements}

This study was supported by grants from the German Research Foundation (PA 2377 1/1; FOR 918) and German Academic Exchange Service (DAAD) within a PPP program (57051794), and a grant from the US National Science Foundation (Grant No. 1354659). The seeds for the experiment were kindly supplied by Dr. Timothy George (Ecological Sciences, The James Hutton Institute, Dundee, Scotland UK). We would like to thank Jenna Merrilees, Susann Enzmann, and Karin Schmidt for their help during the setup and analyses of the experiment. 


\section{References}

Allison, S.D., Weintraub, M.N., Gartner, T.B., Waldrop, M.P., 2011. Evolutionaryeconomic principles as regulators of soil enzyme production and ecosystem function. In: Shukla, G.C., Varma, A. (Eds.), Soil Enzymology. SpringerVerlag, Berlin Heidelberg, pp. 229-243.

Amundson, R., 2001. The carbon budget in soils. Annual Review of Earth and Planetary Sciences 29, 535-562.

Bailey, V.L., Peacock, A.D., Smith, J.L., Bolton Jr., H., 2002. Relationships between soil microbial biomass determined by chloroform fumigation-extraction, substrate-induced respiration, and phospholipid fatty acid analysis. Soil biology and Biochemistry 34, 1385-1389.

Beier, S., Bertilsson, S., 2013. Bacterial chitin degradation-mechanisms and ecophysiological strategies. Frontiers in Microbiology 4 (149).

Bertin, C., Yang, X., Weston, L.A., 2003. The role of root exudates and allelochemicals in the rhizosphere. Plant and Soil 256, 67-83.

Blagodatskaya, E., Kuzyakov, Y., 2008. Mechanisms of real and apparent priming effects and their dependence on soil microbial biomass and community structure: critical review. Biology and Fertility of Soils 45, 115-131.

Bucher, M., 2007. Functional biology of plant phosphate uptake at root and mycorrhizal interfaces. New Phytologist 173, 11-26.

Cheng, W., Dijkstra, F.A., 2007. Theoretical proof and empirical confirmation of a continuous labeling method using naturally ${ }^{13} \mathrm{C}$-depleted carbon dioxide. Journal of Integrative Plant Biology 49, 401-407.

Cheng, W., Johnson, D.W., Fu, S., 2003. Rhizosphere effects on decomposition: Controls of plant species, phenology, and fertilization. Soil Science Society of America Journal 67, 1418-1427. 
Cheng, W., Johnson, D.W., 1998. Elevated $\mathrm{CO}_{2}$, rhizosphere processes, and soil organic matter decomposition. Plant and Soil 202, 167-174.

Cheng, W., Kuzyakov, Y., 2005. Root effects on soil organic matter decomposition, in: Zobel, R.W., Wright, S.F. (Eds.), Roots and Soil Management: Interactions between Roots and the Soil. ASA-SSSA, Madison, Wisconsin, pp. 119-143.

Cheng, W.; Parton, W.J.; Gonzalez-Meler, M.A.; Phillips, R.; Asao, S.; McNickle, G.G.; Brzostek, E.; Jastrow, J.D., 2014. Synthesis and modeling perspectives of rhizosphere priming, New Phytologist 201, 31-44.

Crain, J.M., Morrow, C., Fierer, N., 2007. Microbial nitrogen limitation increases decomposition. Ecology 88, 2105-2113.

De Cesare, F., Garzillo, A.M.V., Buonocore, V., Badalucco, L., 2000. Use of sonication for measuring acid phosphatase activity in soil. Soil Biology and Biochemistry 32, 825- 832 .

Dennis, P.G., Miller, A.J., Hirsch, P.R., 2010. Are root exudates more important than other sources of rhizodeposits in structuring rhizosphere bacterial communities? FEMS Microbial Ecology 72, 313-327.

Dictor, M.-C., Tessier, L., Soulas, G., 1998. Reassessment of the $\mathrm{K}_{\mathrm{EC}}$ coefficient of the fumigation-extraction method in a soil profile. Soil Biology and Biochemistry $30,119-127$.

Duo-Chuan, L., 2006. Review of fungal chitinases. Mycopathologia 161, 345-360.

Ekenler, M., Tabatabai, M.A., 2002. B-Glucosaminidase activity of soils: effect of cropping systems and its relationship to nitrogen mineralization. Biology and Fertility of Soils $36,367-376$.

Finzi, A.C.; Abramoff, R.Z.; Spiller, K.S.; Brzostek, E.R.; Darby, B.A.; Kramer, M.A.; Phillips, R.P., 2015. Rhizosphere processes are quantitatively omportant 
components of terrestrial carbon and nutrient cycles. Global Change Biology doi:10.1111/geb.12816.

Fontaine, S.; Barot, S.; Barre, P.; Bdioui, N.; Mary, B.; Rumpel, C., 2007. Stability of organic carbon in deep soil layers controlled by fresh carbon supply. Nature 450, 277-280.

Fu, S., Cheng, W., 2002. Rhizosphere priming effects on the decomposition of soil organic matter in C4 and C3 grassland soils. Plant and Soil 238, 289-294.

Gahoonia, T.S., Nielsen, N.E.; Joshi, P.A.; Jahoor, A., 2001. A root hairless barley mutant for elucidationg genetic of root hairs and phosphorus uptake. Plant and Soil 235, 211-219.

Gahoonia, T.S.; Nielsen, N.E., 2003. Phosphorus (P) uptake and growth of a root hairless barley mutant (bald root barley, brb) and wild type in low- and high-P soils. Plant, Cell and Environment 26, 1759-1766.

Geisseler, D., Horwath, W.R., Joergensen, R.G., Ludwig, B., 2010. Pathways of nitrogen utilization by soil microorganisms - A review. Soil Biology and Biochemistry 42, 2058-2067.

Harris, D., Porter, L.K., Paul, E.A., 1997. Continuous flow isotope ratio mass spectrometry of carbon dioxide trapped as strontium carbonate. Communications in Soil Science and Plant Analysis 28, 747-757.

Jones, D.L., Nguyen, C., Finlay, R.D., 2009. Carbon flow in the rhizosphere: carbon trading at the soil-root interface. Plant and Soil 321, 5-33.

Jungk, A., 2001. Root hairs and the acquisition of plant nutrients from soil. Journal of plant nutrition and soil science 164, 121-129.

Kelly, A.M.; Fay, P.A.; Polley, H.W.; Gill, R.A.; Jackson, R.B., 2011. Atmospheric $\mathrm{CO}_{2}$ and soil extracellular enzyme activity: a meta-analysis and $\mathrm{CO}_{2}$ gradient experiment. Ecosphere 2(8):art96 (DOI:10.1890/ES11-00117.1). 
Kramer, M.G., Sollins, P., Sletten, R., Swart, P.K., 2003. N isotope fractionation and measures of organic matter alteration during decomposition. Ecology 845, 20212025.

Kuzyakov, Y., 2002. Review: Factors affecting rhizosphere priming effects. Journal of Plant Nutrition and Soil Science 165, 382-396.

Kuzyakov, Y., 2006. Sources of $\mathrm{CO}_{2}$ efflux from soil and review of partitioning methods. Soil Biology and Biochemistry 38, 425-448.

Lambers, H., Shane, M.W., Cramer, M.D., Pearse, S.J., Veneklaas, E.J., 2006. Root structure and functioning for efficient acquisition of phosphorus: matching morphological and physiological traits. Annals of Botany 98, 693-713.

Loeppmann, S., Blagodatskaya, E., Pausch, J., Kuzyakov, Y., 2016. Substrate quality affects kinetics and catalytic efficiency of exo-enzymes in rhizosphere and detritusphere. Soil Biology and Biochemistry 92, 111-118.

López-Bucio, J., Cruz-Ramírez, A., Herrera-Estrella, L., 2003. The role of nutrient availability in regulating root architecture. Current Opinion in Plant Biology 6, 280-287.

Marx, M., Wood, M., Jarvis, S., 2001. A fluorimetric assay for the study of enzyme diversity in soils. Soil Biology and Biochemistry 33, 1633-1640.

Marx, M.-C., Kandeler, E., Wood, M., Wermbter, N., Jarvis, S.C., 2005. Exploring the enzymatic landscape: distribution and kinetics of hydrolytic enzymes in soil particle-size fractions. Soil Biology and Biochemistry 37, 35-48.

McDougall, B.M., Rovira, A.D., 1970. Sites of exudation of ${ }^{14} \mathrm{C}$-labelled compounds from wheat roots. New Phytologist 69, 999-1003.

Motulsky, H.M., Brown, R.E., 2006. Detecting outliers when fitting data with nonlinear regression - a new method based on robust nonlinear regression and the false discovery rate, BMC Bioinformatics 7, 123. 
Mwafulirwa, L., Baggs, E.M., Russell, J., George, T., Morley, N., Sim, A., de la Fuente Cantó, C., Paterson, E., 2016. Barley genotype influences stabilization of rhizodeposition-derived $\mathrm{C}$ and soil organic matter mineralization. Soil Biology and Biochemistry 95, 60-69.

Nguyen, C., 2003. Rhizodeposition of organic C by plant: mechanisms and controls. Agronomie 23, 375-396.

Olander, L.P., Vitousek, P.M., 2000. Regulation of soil phosphatase and chitinase activity by $\mathrm{N}$ and $\mathrm{P}$ availability. Biogeochemistry $49,175-190$.

Paterson, E., 2003. Importance of rhizodeposition in the coupling of plant and microbial productivity. European journal of Soil Science 54, 741-750.

Paterson, E., Sim, A., 2013. Soil-specific response functions of organic matter mineralization to the availability of labile carbon. Global Change Biology 19, $1562-1571$.

Pausch, J., Kuzyakov, Y., 2011. Photoassimilates allocation and dynamics of hotspots in roots visualized by ${ }^{14} \mathrm{C}$ phosphor imaging. Journal of Plant Nutrition and Soil Science 174, 12-19.

Pausch, J., Zhu, B., Kuzyakov, Y., Cheng, W., 2013. Plant inter-species effects on rhizosphere priming of soil organic matter decomposition. Soil Biology and Biochemistry 57, 91-99.

Schimel, J.P., Schaeffer, S.M., 2012. Microbial control over carbon cycling in soil. Frontiers in Microbiology 3, 348.

Schlesinger, W.H., Andrews, J.A., 2000. Soil respiration and the global carbon cycle. Biogeochemistry 48, 7-20.

Sinsabaugh, R.L., Moorhead, D.L., 1994. Resource allocation to extracellular enzyme production: a model for nitrogen and phosphorus control of litter decomposition. Soil Biology and Biochemistry 26 (10), 1305-1311. 
Spohn, M., Kuzyakov, Y., 2014. Spatial and temporal dynamics of hotspots of enzyme activity as affected by living and dead roots - A soil zymography analysis. Plant and Soil 79 (1-2), 67-77.

Vance, E.D., Brookes, P.C., Jenkinson, D.S., 1987. An extraction method for measuring soil microbial biomass C. Soil Biology and Biochemistry 19 (9) 703707.

Weintraub, M.N., Schimel, J.P., 2005. Seasonal protein dynamics in Alaskan arctic tundra soils. Soil Biology and Biochemistry 37, 1469-1475.

Wu, J., Jörgensen, R.G., Pommerening, B., Chaussod, R., Brookes, P.C., 1990. Measurement of soil microbial biomass-C by fumigation-extraction - an automated procedure. Soil Biology and Biochemistry 22, 1167-1169.

Zhu, B., Cheng, W., 2011. ${ }^{13} \mathrm{C}$ isotope fractionation during rhizosphere respiration of C3 and C4 plants. Plant and Soil 342, 277-287.

Zhu, B., Cheng, W., 2012. Nodulated soybean enhances rhizosphere priming effects on soil organic matter decomposition more than non-nodulated soybean. Soil Biology and Biochemistry 51, 56-65. 


\section{Figure captions}

Figure 1: Light microscopy images of the barley wild type and the root-hairless barley mutant germinated in deionized water.

Figure 2: Potential enzyme activities for a) $\beta$-glucosidase, b) $\beta$-cellobiohydrolase, c) $\beta$-xylosidase, d) chitinase, e) leucine-aminopeptidase (LAP), and f) acid phosphatase ( \pm SEM) at tillering (T1) and head-emergence stage (T2) for unplanted soil (US), the barley wild type (WT) and the root-hairless barley mutant (brb). Bars labelled by different lowercase letters indicate significant differences $(P \leq 0.05)$ between the treatments at one sampling date. Significant differences between T1 and T2 are indicated by an asterisk.

Figure 3: SOM-derived $\mathrm{CO}_{2}$ (top) and root-derived $\mathrm{CO}_{2}$ (bottom) at $\mathrm{T} 1$ (left) and $\mathrm{T} 2$ (right). Bars labelled by different lowercase letters indicate significant differences $(P \leq 0.05)$ between the treatments at one sampling date. Significant differences between $\mathrm{T} 1$ and $\mathrm{T} 2$ are indicated by an asterisk. The inlet shows the root-derived $\mathrm{CO}_{2}$ per $\mathrm{g}$ root for both barley types and sampling stages.

Figure 4: Rhizosphere priming effects per root dry weight and time ( \pm SEM) (left axis, bars) and as \% of the unplanted soil ( \pm SEM) (right axis, dots) at T1 and T2 in treatments with a barley wild type (WT) and a root hairless barley mutant (brb). Bars or dots labelled by different letters indicate significant differences $(P \leq 0.05)$ between the treatments. Significant differences between T1 and T2 are indicated by asterisk. The $P$ values from a t-test to test for significant deviation of RPE (\% of unplanted soil) from zero are shown. 


\section{Tables}

Table 1: End member values ( \pm SEM) used in two-source isotopic mixing models, in order to calculate the contribution of SOM-derived $\mathrm{CO}_{2}$ to total soil $\mathrm{CO}_{2}$ of the planted treatments, at tillering (T1) and head-emergence stage (T2) for unplanted soil (US), the barley wild type (WT) and the root-hairless barley mutant (brb). The sample size is given in parentheses.

\begin{tabular}{llll}
\hline Sampling time & Treatment & $\begin{array}{l}\text { Root-derived } \mathrm{CO}_{2} \\
{[\% \text { o] }}\end{array}$ & $\begin{array}{l}\text { SOM-derived } \mathrm{CO}_{2} \text { of the } \\
\text { unplanted soil [\%] }\end{array}$ \\
\hline T1 & US & $-24.20 \pm 0.51(4)$ \\
& WT & $-38.65 \pm 0.28(3)$ & \\
& brb & $-39.65 \pm 0.36(4)$ & \\
T2 & US & & $-24.90 \pm 0.22(4)$ \\
& WT & $-38.57 \pm 0.22(6)$ & \\
& brb & $-39.29 \pm 0.21(4)$ & \\
\hline
\end{tabular}


Table 2: Plant (shoot and root) biomass, $\mathrm{C}$ and $\mathrm{N}$ contents, $\mathrm{C} / \mathrm{N}$ ratios, and $\delta^{13} \mathrm{C}$ and $\delta^{15} \mathrm{~N}$ values ( \pm SEM) 30 (T1) and 65 (T2) days after planting. Significant differences $(P \leq 0.05)$ between the treatments are indicated by different lowercase letters. The asterisk indicates significant differences between $\mathrm{T} 1$ and $\mathrm{T} 2$.

\begin{tabular}{|c|c|c|c|c|c|}
\hline & Sampling time & \multicolumn{2}{|c|}{$\mathrm{T} 1$} & \multicolumn{2}{|c|}{ T2 } \\
\hline & Treatment & WT & brb & WT & brb \\
\hline \multirow{6}{*}{ Shoot } & Biomass [gow pot ${ }^{-1}$ ] & $3.03 \pm 0.13 b$ & $3.70 \pm 0.07 a$ & $38.87 \pm 2.38 a^{*}$ & $30.70 \pm 2.54 a^{*}$ \\
\hline & C content [\%] & $34.08 \pm 0.74 a$ & $34.51 \pm 0.31 \mathrm{a}$ & $38.67 \pm 0.21 a^{*}$ & $37.69 \pm 0.69 a^{*}$ \\
\hline & N content [\%] & $6.15 \pm 0.06 a$ & $6.08 \pm 0.09 a$ & $1.47 \pm 0.10 \mathrm{a}^{*}$ & $1.87 \pm 0.16 \mathrm{a}^{*}$ \\
\hline & $\mathrm{C} / \mathrm{N}$ & $5.54 \pm 0.08 a$ & $5.67 \pm 0.05 a$ & $26.72 \pm 2.09 \mathrm{a}^{*}$ & $20.64 \pm 1.95 a^{*}$ \\
\hline & $\delta^{13} \mathrm{C}[\% \circ]$ & $-41.45 \pm 0.05 a$ & $-41.40 \pm 0.10 a$ & $-38.75 \pm 0.10 a^{*}$ & $-39.75 \pm 0.42 a^{\star}$ \\
\hline & $\delta^{15} \mathrm{~N}[\% 0]$ & $5.23 \pm 0.28 a$ & $5.07 \pm 0.21 \mathrm{a}$ & $6.13 \pm 0.40 \mathrm{a}$ & $5.67 \pm 0.50 \mathrm{a}$ \\
\hline \multirow{6}{*}{ Root } & Biomass [gow pot ${ }^{-1}$ ] & $1.65 \pm 0.04 a$ & $1.88 \pm 0.43 a$ & $12.30 \pm 1.21 \mathrm{a}^{*}$ & $7.37 \pm 0.90 b^{*}$ \\
\hline & C content [\%] & $21.13 \pm 2.69 a$ & $23.04 \pm 3.18 a$ & $32.14 \pm 0.96 \mathrm{a}^{*}$ & $34.99 \pm 1.83 a^{*}$ \\
\hline & N content [\%] & $1.61 \pm 0.35 a$ & $1.68 \pm 0.26 a$ & $1.27 \pm 0.11 \mathrm{a}$ & $1.47 \pm 0.15 a$ \\
\hline & $\mathrm{C} / \mathrm{N}$ & $13.89 \pm 1.29 a$ & $13.88 \pm 0.46 a$ & $25.94 \pm 1.75 \mathrm{a}^{*}$ & $24.57 \pm 2.47 a^{*}$ \\
\hline & $\delta^{13} C[\% 0]$ & $-37.84 \pm 0.21 a$ & $-38.78 \pm 0.36 a$ & $-37.70 \pm 0.27 a$ & $-38.46 \pm 0.33 a$ \\
\hline & $\delta^{15} \mathrm{~N}[\% 0]$ & $3.61 \pm 0.63 a$ & $2.51 \pm 0.27 a$ & $5.87 \pm 0.25 a^{*}$ & $5.53 \pm 0.33 a^{*}$ \\
\hline Shoot/F & & $1.91 \pm 0.11 a$ & $2.21 \pm 0.35 a$ & $3.37 \pm 0.63 a$ & $4.25 \pm 0.31 a^{*}$ \\
\hline
\end{tabular}


Table 3: Dissolved nitrogen (DN), available phosphorus (Bray-P), and chloroform-labile microbial biomass $\mathrm{C}$ and $\mathrm{N}$, at tillering (T1) and head-emergence stage (T2) for unplanted soil (US), the barley wild type (WT) and the root-hairless barley mutant (brb).

Significant differences $(P \leq 0.05)$ between the treatments are indicated by different lowercase letters. The asterisk indicates significant differences between $\mathrm{T} 1$ and $\mathrm{T} 2$.

\begin{tabular}{|c|c|c|c|c|c|c|}
\hline Sampling time & & T1 & & & T2 & \\
\hline Treatment & US & WT & $b r b$ & US & WT & $b r b$ \\
\hline $\begin{array}{l}\mathrm{K}_{2} \mathrm{SO}_{4}- \\
\text { extractable DN } \\
\text { [mg N kg }{ }^{-1} \text { soil] }\end{array}$ & $104.62 \pm 4.68 \mathrm{a}$ & $57.13 \pm 1.34 \mathrm{~b}$ & $57.74 \pm 3.18 b$ & nd & $15.00 \pm 1.71 \mathrm{a}^{*}$ & $15.61 \pm 1.59 a^{*}$ \\
\hline $\begin{array}{l}\text { Bray-P } \\
{\left[\mathrm{mg} \mathrm{P} \mathrm{kg}^{-1} \text { soil] }\right.}\end{array}$ & $66.71 \pm 1.87 a$ & $62.74 \pm 0.69 a$ & $66.79 \pm 1.20 \mathrm{a}$ & $68.35 \pm 1.58 a$ & $60.82 \pm 2.52 a$ & $59.92 \pm 1.70 \mathrm{a}^{*}$ \\
\hline $\begin{array}{l}\text { Chloroform- } \\
\text { labile MBC } \\
\text { [mg C kg-1 soil] }\end{array}$ & $67.60 \pm 5.41 a$ & $62.03 \pm 2.72 a$ & $66.61 \pm 6.26 a$ & $81.25 \pm 7.55 a$ & $101.46 \pm 14.42 \mathrm{a}^{*}$ & $92.21 \pm 7.16 \mathrm{a}^{*}$ \\
\hline $\begin{array}{l}\text { Chloroform- } \\
\text { labile MBN } \\
\text { [mg N kg-1 soil] }\end{array}$ & $8.92 \pm 1.77 a$ & $6.72 \pm 1.81 \mathrm{a}$ & $8.66 \pm 0.39 a$ & $10.21 \pm 1.93 a$ & $13.19 \pm 1.33 \mathrm{a}^{*}$ & $14.49 \pm 1.21 \mathrm{a}^{*}$ \\
\hline $\mathrm{MBC} / \mathrm{MBN}$ & $8.70 \pm 2.18 \mathrm{a}$ & $11.41 \pm 2.71 a$ & $7.84 \pm 1.13 a$ & $9.47 \pm 3.05 a$ & $7.67 \pm 0.56 \mathrm{a}$ & $6.48 \pm 0.63 a$ \\
\hline
\end{tabular}




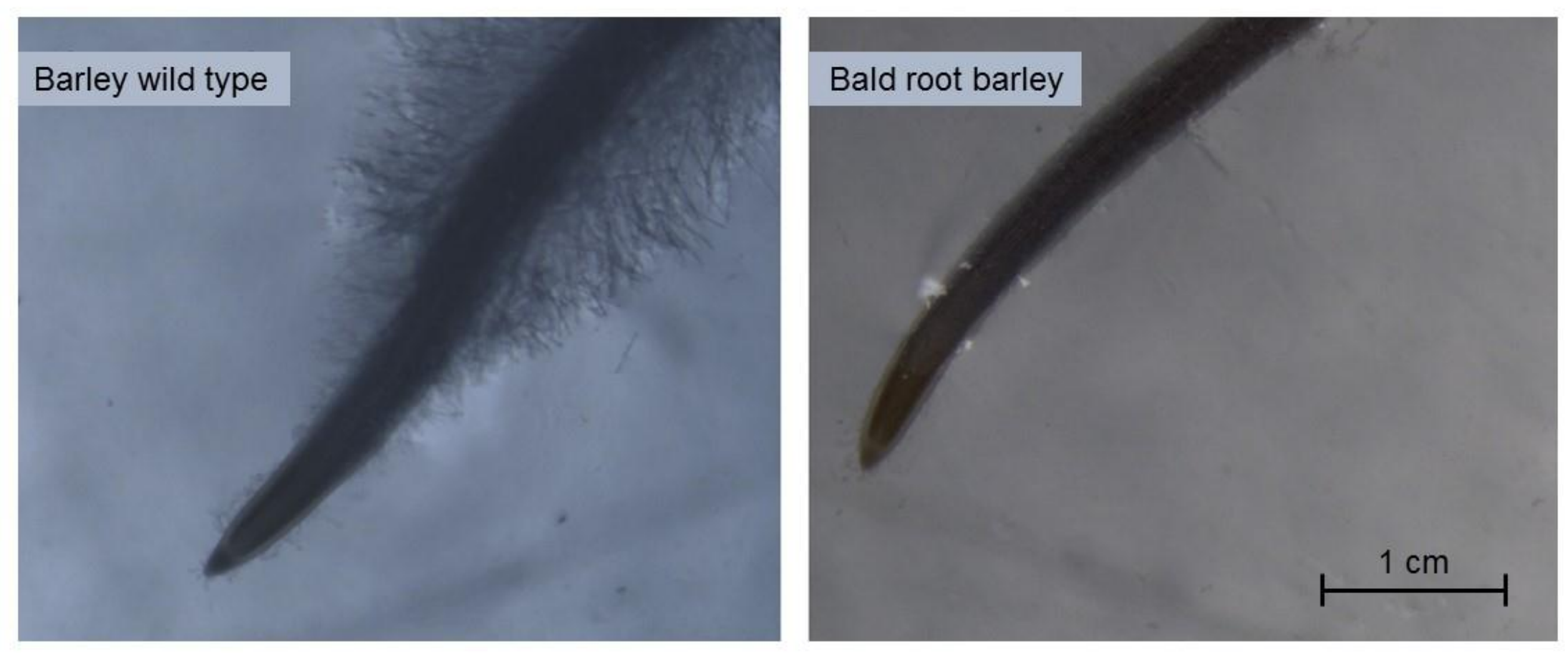



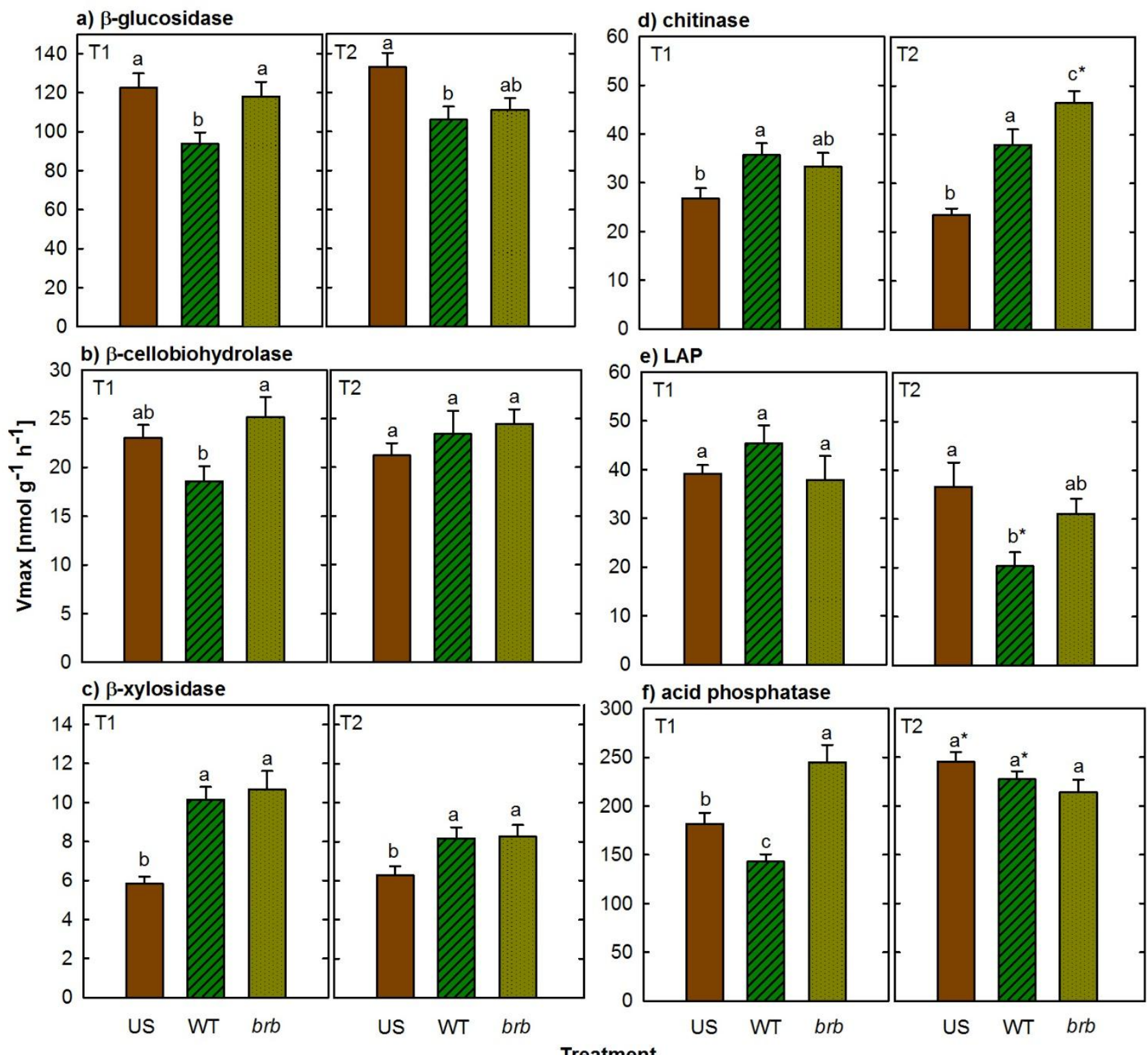

300 f) acid phosphatase

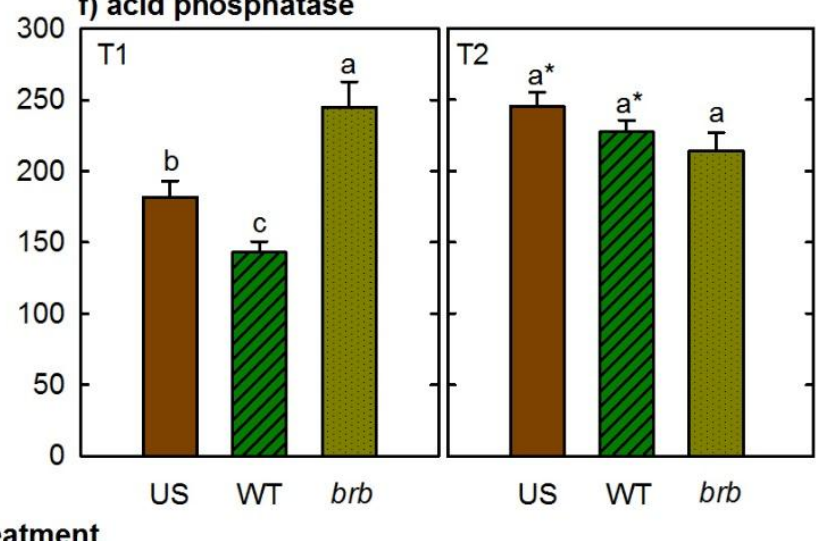



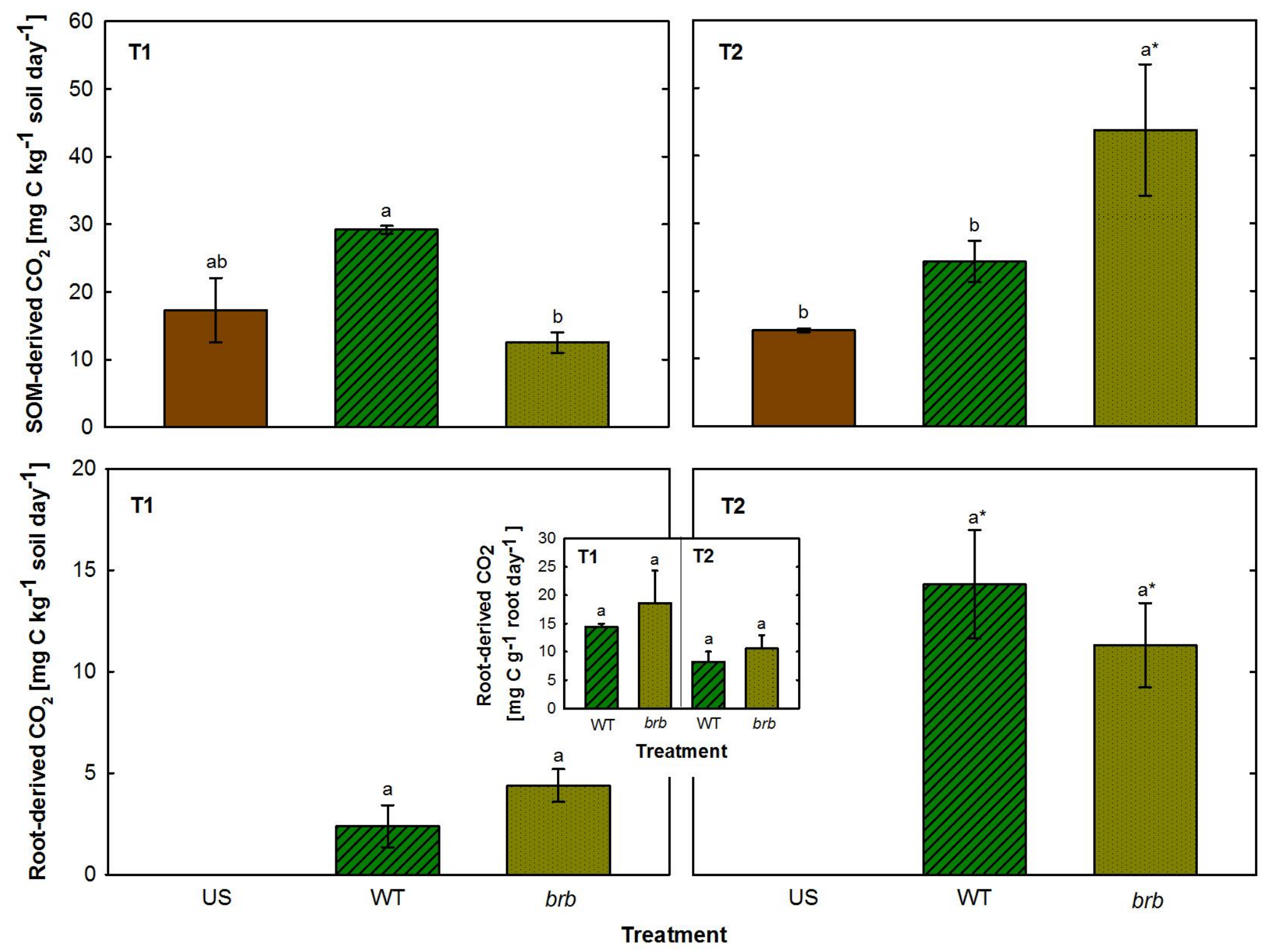


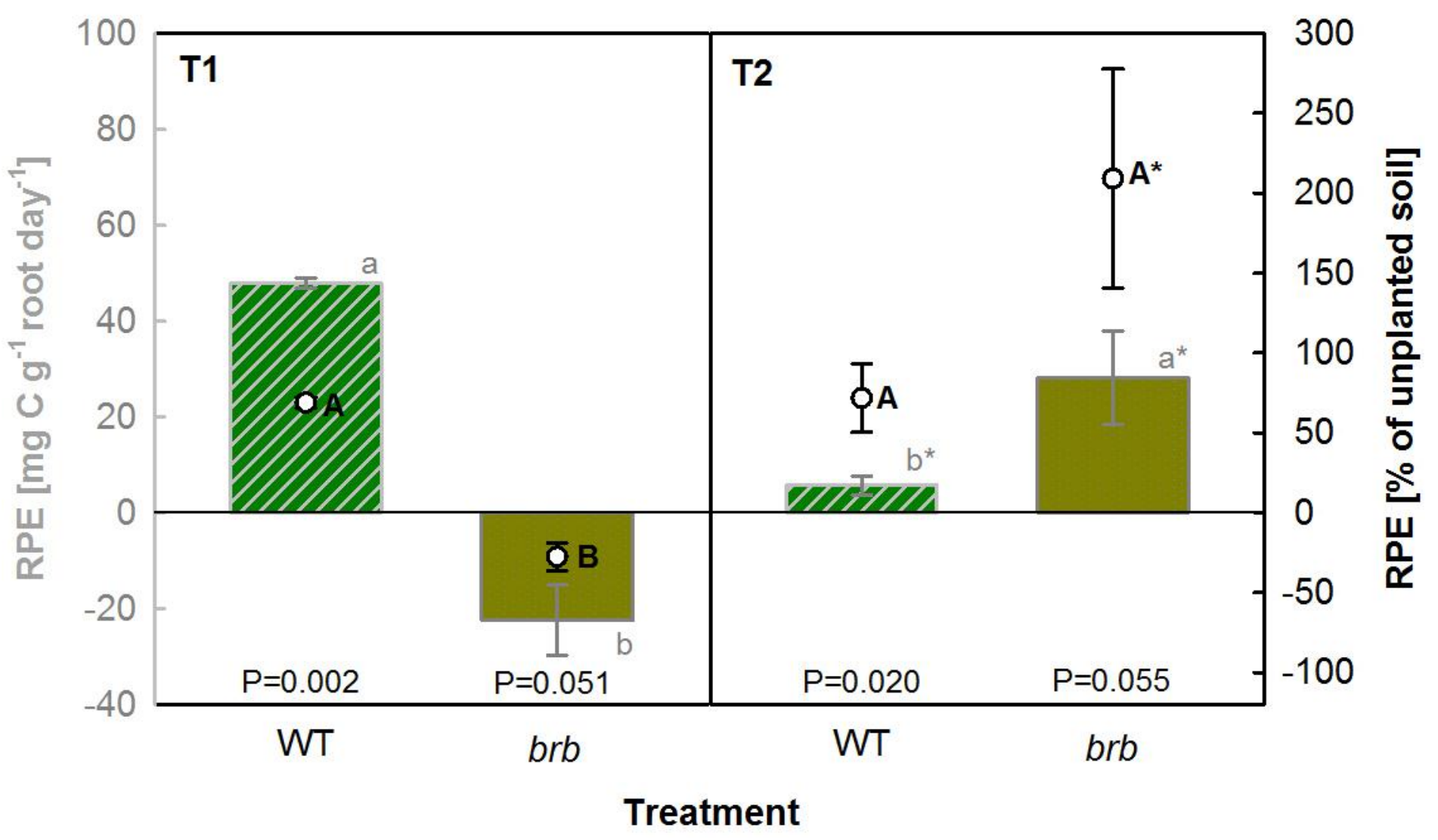




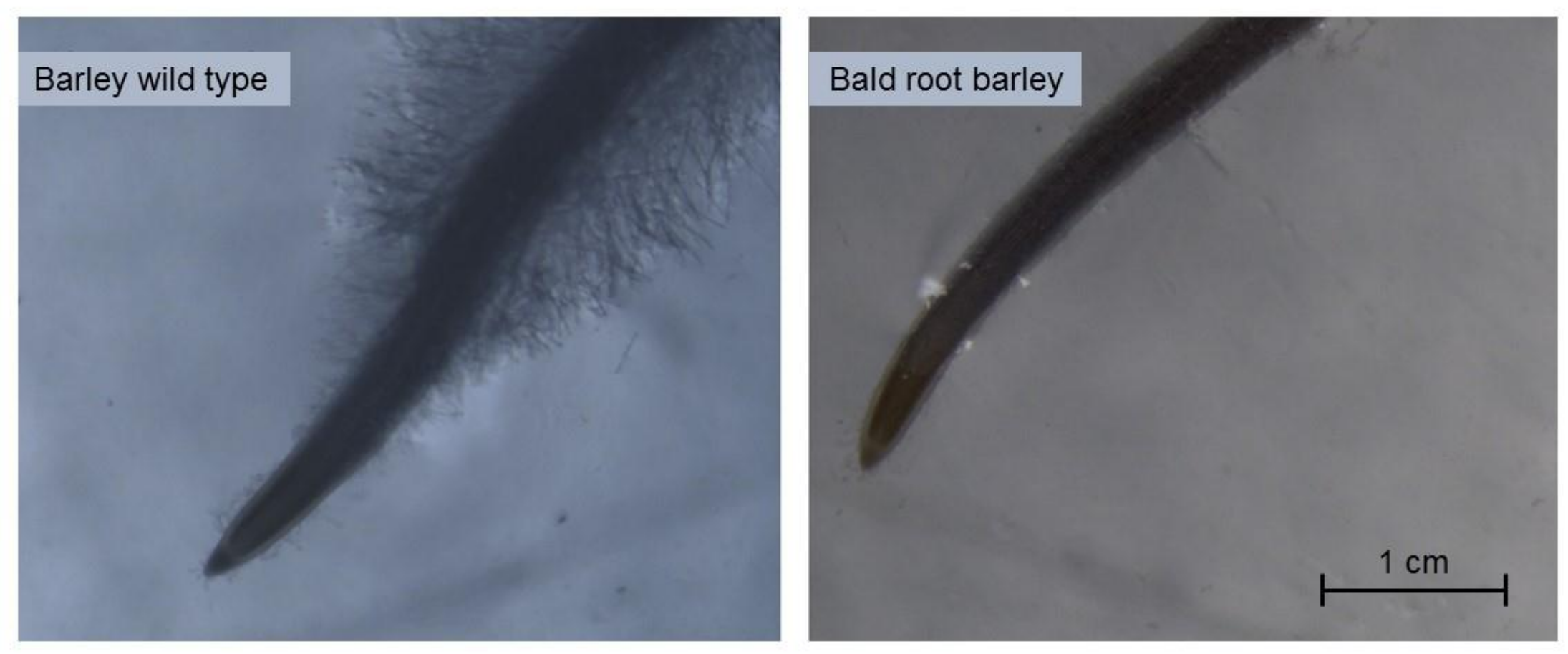

